THE END OF ART 



\section{THE END OF ART}

Readings in a Rumor after Hegel

\section{Eva Geulen}

Translated by James McFarland

STANFORD UNIVERSITY PRESS

STANFORD, CALIFORNIA 2006 
Stanford University Press

Stanford, California

(C) 2006 by the Board of Trustees of the Leland Stanford Junior University. All rights reserved.

The End of Art was published in German in 2002 under the title Das Ende der Kunst: Lesarten eines Gerüchts nach Hegel (C) 2002, (C) Suhrkamp Verlag Frankfurt am Main.

No part of this book may be reproduced or transmitted in any form or by any means, electronic or mechanical, including photocopying and recording, or in any information storage or retrieval system without the prior written permission of Stanford University Press.

Printed in the United States of America on acid-free, archival-quality paper

Library of Congress Cataloging-in-Publication Data

Geulen, Eva.

[Ende der Kunst. English]

The end of art : readings in a rumor after Hegel / Eva Geulen ; translated by James McFarland.

p. $\mathrm{cm}$.

Includes bibliographical references and index.

ISBN-IO: 0-8047-4423-8 (cloth : alk. paper)

ISBN-IO: 0-8047-4424-6 (pbk. : alk. paper)

ISBN-I3: 978-0-8047-4423-2 (cloth : alk. paper)

ISBN-I3: 978-0-8047-4424-9 (pbk. : alk. paper)

I. Aesthetics-Philosophy. 2. Art-Philosophy. I. Title. II. Series.

$\mathrm{BH}_{39} \cdot \mathrm{G}_{4913} 2006$

III'.85--dc22 